\title{
Biological Significance of Glycosylphosphatidylinositols in Protozoan Parasites
}

\section{原生動物寄生虫におけるグリコシルホスファチジルイノシトールの生物学的意義}

\author{
Garg, Nisha \\ Department of Cellular Biology, 724 Biological Sciences Building, The University of Georgia, Athens, \\ Georgia 30602, USA, FAX: 1-706-542-4271, E-mail: ngarg@cb.uga.edu
}

Key Words : biosynthesis, glycosylphosphatidylinositol, infectivity and survival, inhibitors, protozoans

\begin{abstract}
Parasitic protozoans including the members of trypanosomatidae family are the cause of diseases in humans and livestock. A majority of the glycoproteins present on plasma membrane of these parasites are attached by glycosylphosphatidylinositol (GPI)-anchor. In addition, plasma membrane of some of the protozoans is decorated with free GPIs which are not attached to proteins. The structure and biosynthesis of GPIs in protozoans as compared to higher eukaryotes and their utility as targets for anti-protozoan chemotherapy is discussed. The crucial role of GPIs and GPI-attached glycoproteins in protozoan parasites infectivity and survival is the focus of this review.
\end{abstract}

\section{A. Introduction}

Glycosylphosphatidylinositol (GPI) anchors attach a diverse group of macromolecules to the plasma membrane of eukaryotes. In "higher" eukaryotes, GPIs are found on a minor group of proteins. In kinetoplastids, a majority of the cell surface proteins are GPI-anchored. Parasitic protozoans including members of the trypanosomatidae family (e.g. African trypanosomes, Trypanosoma cruzi, Leishmania sp.), Toxoplasma, Plasmodium, and Theileria cause diseases in humans and livestock. GPI-attached glycoproteins in these organisms have been implicated in a number of biological processes related to parasitism and pathogenesis. In addition, the plasma membrane of some of the parasitic protozoans is decorated with GPIs that are not attached to proteins. Our current understanding of the biosynthesis of GPIs, and their possible function in protozoan parasites physiology, infectivity and virulence will be the focus of this review. Detailed discussion of the structure and biosynthesis of GPIs in protozoans, yeast and mammalian cells can be found in several recent reviews (1-8).
要 約

Trypanosomatidae 族を含む寄生性原生動物は、人、家畜の病 気の原因である。これら寄生虫の原形質膜に存在している糖夕 ンパク質の大部分は、グリコシルホスファチジルイノシトール (GPI)-アンカーにより膜に結合している。加えて何種類かの原生 動物の原形質膜は、タンパク質に結合していないフリーなGPIで 修飾されている。高等な真核生物と比較して原生動物でのGPIの 構造と生合成、また原生動物に対する化学療法のターゲットと してのGPIの利用についても述べたい。原生動物の寄生虫が感染 したり生存していく際のGPIと、GPIのついた糖タンパク質の役 割の重要性について述べることが、この論文の中心である。

\section{A. はじめに}

$$
\text { グリコシルホスファチジルイノシトール(GPI)アンカーは、 }
$$
マクロな分子の多様なグループを、真核生物の原形質膜につな ぎとめている。高等な真核生物において、GPIはマイナーなタン パク質であると見られている。kinetoplastidでは、細胞表面タン パクの大部分がGPIアンカー型である。trypanosomatidae 族(例え ばAfrican trypanosomes、Trypanosoma cruzi、Leishmania sp)、 Toxoplasma、Plasmodium、Theileriaを含む寄生性原生動物は、 人、家畜の病気の原因である。これら生物における GPI結合型糖 タンパク質は、寄生と病因に関連した、多くの生化学プロセス に関係している。加えて、いくつかの寄生虫の原生動物の原形 質膜は、タンパク質のついてないGPIで修飾されている。GPI生 合成に関して今わかっているところと、原生動物寄生虫の生理 学、感染、毒性に関する機能が、この論文の中心となろう。原 生動物、yeast、哺乳類細胞でのGPIの構造と生合成についての詳 しい議論は、いくつかの最近の論文(1-8)を参照されたい。

Abbreviations used: AEP, aminoethylphosphonic acid; CTL, cytotoxic T lymphocytes; EtNP, phosphoethanolamine; GIPL, glycoinositolphospholipid; GlcNAc, N-acetylglucosamine; GlcN, glucosamine; GP63, Leishmania protease; GPI, glycosylphosphatidylinositol; LPG, lipophosphoglycan; LPPG, lipopeptidophosphoglycan; Man, mannose; PARP, Trypanosoma brucei procyclic acid protein; PI, phosphatidylinositol; PI-PLC, PI-specific phospholipase C; VSG, variant surface glycoprotein. 
Trends in Glycoscience and Glycotechnology Vol.10 No.56 (November 1998) pp.439-453

\section{B. Structure of GPI Anchors}

The first protozoan GPI structure was elucidated in $T$. brucei $(9,10)$. Since then GPIs have been characterized from Leishmania (11-13), T. cruzi (14-16), Plasmodium $(17,18)$, Toxoplasma $(19,20)$ and yeast $(21,22)$.

All GPI anchors share a "conserved core" glycan (Mano1-4GlcNo1-6PI) constituted of mannose (Man), glucosamine (GlcN) and phosphatidylinositol (PI). In protein-GPIs, the core is extended by the addition of two mannose residues in $\alpha 1-6$ and $\alpha 1-2$ linkages (Man $\alpha 1-2 \mathrm{Man} \alpha 1-6 \mathrm{Man} \alpha 1-4 \mathrm{GlcN}-\mathrm{PI}$ ) (10). The 6-OH group on the third mannose from the reducing end is attached to phosphoethanolamine (EtNP) (10). Nevertheless, all the known anchors except that of the L. major gp63 $(13,23)$ have various substituents (3). An additional $\alpha$-mannose extension of the tri-mannosyl core present in T. cruzi 1G7-

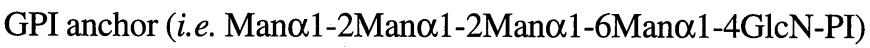
(24) is also common in P. falciparum, yeast and mammalian GPIs. Incorporation of aminoethylphosphonic acid (AEP) in place of $\mathrm{EtNPO}_{4}$ occurs in some $T$. cruzi GPIs $(16,25)$. GPIs with acylation of the 2-OH group of the inositol ring are present on some proteins (e.g. PARP of T. brucei (26) and Tc-85 in $T$. cruzi (27)). The conserved GPI core in $T$. gondii tachyzoites is modified by addition of $\beta$-linked $\mathrm{N}$-acetylgalactosamine residue(s) (28).

The lipid moieties of GPIs exhibit striking diversity depending upon the developmental stage or species of the parasites. Diacylation of a glycerophospholipid moiety is common, but an ether linkage at the sn-1 position of a glycerol backbone is not rare $(13,14,29)$. For example, dimyristoylglycerol is found on VSG-GPI in T. brucei (9), whereas sn-1-alkyl-2acylglycerol is present on the GPI of gp63 of Leishmania (13) and $1 \mathrm{G} 7$ of $T$. cruzi (14). Ceramide may be used in place of the glycerolipid as the source of alkyl groups. In T. cruzi, inositol phosphoceramide is detectable in $10 \%$ of $1 \mathrm{G} 7$ (14), $70 \%$ of metacyclic mucins $(15,16)$ and in amastigote Ssp-4 (30).

Free GPIs, and GPIs attached to polysaccharides are expressed on the plasma membrane of some parasitic protozoans. Lipophosphoglycan (LPG) of $L$. donovani consists of a linear chain of phospho-disaccharide repeat units (-6Galß1-4Man 1 1$\left.\mathrm{HPO}_{4}\right) \mathrm{n}(\mathrm{n}=15-30)$ linked to the plasma membrane by a heptasaccharide core consisting of Gal $\alpha 1-6 \mathrm{Gal} \alpha 1-3 \mathrm{Gal} f ß 1$ 3(Glc $\left.\alpha 1-\mathrm{HPO}_{4}-6\right) \mathrm{Man} \alpha 1-3 \mathrm{Man} \alpha 1-4 \mathrm{GlcN} \alpha 1-6$ myo-Ins-1$\mathrm{HPO}_{4}$-(sn-1-alkyl-2-lyso-glycerol) (31-33). Glycoinositol phospholipids (GIPLs) identified in L. major and $L$. donovani amastigotes contain the conserved glycan core (Mano14GlcNo1-6PI) and are classified based upon the presence of second mannose residue in $\alpha 1-6$ (Type 1), $\alpha 1-3$ (Type 2) or branched (Man 1 1-6(Man $\alpha 1-3$, hybrid GIPLs) conformation (34-37). Lipopeptidophosphoglycan (LPPG) of $T$. cruzi contains a

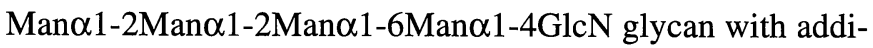
tional $\mathrm{BGal} f$ residues (B1-3 linkage on $\mathrm{Man}_{3-4}$ ), 2-AEP on the 6-

\section{B. GPIアンカーの構造}

初期の原生動物のGPI構造は、T. bruceiで解明された(9、 10)。それ以来、GPIはLeishmania (11-13)、T. cruzi (14-16)、Plasmodium (17、18)、Toxoplasma (19、20)、yeast $(21 、 22)$ で調べら れている。

すべてのGPIアンカーは、マンノース(Man)、グルコサミン $(\mathrm{GlcN}) 、$ ホスファチジルイノシトール(PI)からなる、「保存され たコア」と呼ばれる糖鎖( $\operatorname{Man} \alpha 1-4 \mathrm{GlcN} \alpha 1-6 \mathrm{PI})$ を持つ。タンパ クGPIにおいては、 $\alpha$ 1-6、 $\alpha$ 1-2結合(Man $\alpha$ 1-2Man $\alpha$ 1-6Man $\alpha$ 1-4GlcNPI) した2つのマンノース残基が結合してコアが伸びる (10)。還元末端から、3つ目のマンノースの6-OH基が、ホスファ チジルエタノールアミン(EtNP)に結合している(10)。その一方 で、L. major gp63を除いて(13、23)、知られているすべてのア ンカーは、さまざまに置換されている(3)。トリマンノシル化し たコアに $\alpha$-マンノースが付加することで伸長した構造が、T. cruzi 1G7-GPIアンカー(Man $\alpha$ 1-2Man $\alpha$ 1-2Man $\alpha 1$-6Man $\alpha 1$ 4GlcN-PI) (24)に存在しており、P. falciparum、yeast、哺乳類の GPIにも共通である。いくつかのT. cruzi GPIでEtNPO ${ }_{4}$ の位置に アミノエチルホスホニル酸(AEP)が結合している(16、25)。イノ シトール環の2-OH基がアシル化したGPIは、いくつかのタンパ ク質に存在している(例えばT. brucei (26)のPARPと T. cruziのTc85)。T. gondii tachyzoiteの保存されたGPIコアは、 $\beta$ 結合したNアセチルグルコサミン残基の付加により修飾される(28)。

GPIの脂質部分は、発達段階や寄生虫の種に依存した際だっ た多様性を示す。グリセロリン脂質はジアシル化されている場 合が一般的であるが、グリセロール骨格のsn1位のエーテル結合 もまれというわけではない(13、14、29)。例えば、ジミリストイ ルグリセロールはT. brucei (9)のVSG-GPIで見られ、それに対 し、sn-1-alkyl-2acylglycerolは、Leishmania (13) のgp63のGPIと T. cruzi (14)の1G7のGPIで存在する。セラミドは、アルキル鎖の供 給源としてグリセロ脂質の代わりに使われているようだ。 $T$. cruziにおいて、イノシトールホスホセラミドは、1G7の10\% (14)、metacyclic mucins (15、16)、amastigote Ssp-4 (30)の70\%に 見られる。

フリーなGPIと多糖のついたGPIは、何種かの原生動物の寄 生虫の原形質膜上に発現している。L.donovaniのリポホスホグリ カン(LPG)は、Gal $\alpha 1-6 \mathrm{Gal} \alpha 1-3 \mathrm{Gal} f \beta 1-3\left(\mathrm{Glc} \alpha 1-\mathrm{HPO}_{4}-6\right) \mathrm{Man} \alpha$

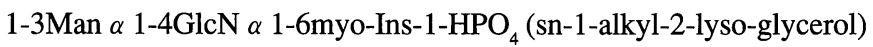
(31-33) からなる7糖コアにより原形質膜に結合しており、直鎖 のリン酸化2糖の繰り返し単位(-6Gal $\left.\beta 1-4 \mathrm{Man} \alpha 1-\mathrm{HPO}_{4}\right) \mathrm{n}(\mathrm{n}=15-$ 30)からなる。L. majorとL. donovani amastigoteで確認したグリコ シルイノシトールリン脂質(GIPLs)は、保存された糖コア(Man $\alpha$ 1-4GlcN $\alpha$ 1-6PI)を含み、また、 $\alpha$ 1-6(Type1)、 $\alpha$ 1-3(Type2)での 2番目のマンノース残基の存在や枝分れした(Man $\alpha$ 1-6と Man $\alpha$ 13が混ざったGIPLs)構造に基づいて分類される(34-37)。T. cruziの リポペプチドリン酸化糖(LPPG)は、付加した $\beta \mathrm{Gal}$ フラノース残 基(Man3-4に $\beta$ 1-3結合している)、GlcNの6位で2-AEP、アルキル グリセロールの変わりにセラミドを結合したMan $\alpha 1-2 \operatorname{Man} \alpha 1-$ 


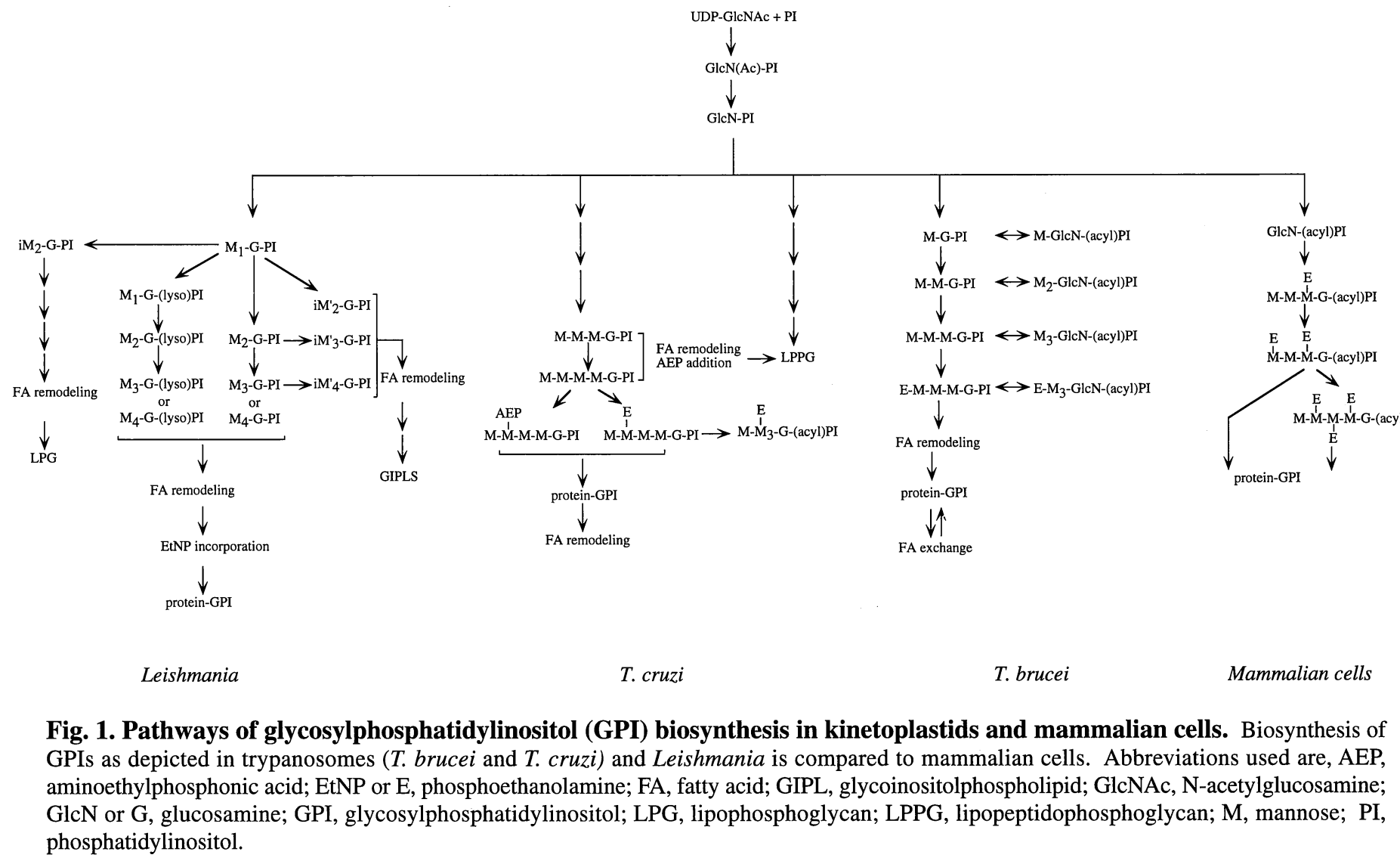

position of GlcN, and ceramide instead of alkylacylglycerol (38$40)$.

\section{GPI Biosynthesis}

GPI biosynthesis was first studied in a T. brucei cell free system (Fig. 1). Since then, GPI biosynthesis in other protozoans $(19,41)$, mammalian cells $(42-44)$ and yeast (45) has been described (Fig. 1).

The first two steps in GPI biosynthesis are common to all biological systems. Transfer of $\mathrm{N}$-acetylglucosamine (GlcNAc) to PI utilizing UDP-GlcNAc as the activated donor, to form GlcNAc-PI, is followed by deacetylation to form $\mathrm{GlcN}$ PI (46). Based upon the experiments done using intact microsomes prepared from trypanosomes or mammalian cells, these reactions appear to occur on the cytoplasmic side of endoplasmic reticulum (ER) (47). Sensitivity to cytosolic phospholipase C of Dol-P- $\left[{ }^{3} \mathrm{H}\right] \mathrm{Man}$ incorporation into GPI precursors in vitro to form $\mathrm{Man}_{3}$-GlcN-PI in T. brucei membranes further (48) suggests that GPI intermediates are predominantly localized on the cytosolic ER membranes. EtN-phospho-Man ${ }_{3}$-GlcN-PI is also detected on the cytoplasmic leaflet of ER membranes in $T$. brucei (48). The completed GPI synthesized cytosollically appears to flip into the ER lumen where its transfer to protein occurs. A protein GPI transamidase (PGTase) then catalyzes GPI addition to protein (49-51).
2Man $\alpha$ 1-6Man $\alpha$ 1-4GlcN glycanを含む(38-40)。

\section{GPI生合成}

GPI生合成は最初 $T$. brucei のcell free systemで研究された。 それ以来他の原生動物(19、41)、哺乳類細胞(42-44)、そして yeast(45)でのGPI生合成が報告されてきている(図1)。

GPI生合成の最初の $2 つ$ のテップは、すべての生物システ ムに共通である。GlcNAc-PIを作るため、活性供与体として UDP-GlcNAcを用いて、PIにN-アセチルグルコサミン(GlcNAc)を 転移し、続いてGlcN-PIを作るために脱アセチル化する(46)。

Trypanosomeあるいは、哺乳類細胞から用意した無傷のミクロ ソームを使って行った実験に基づくと、これらの反応は小胞体 (ER)の細胞質側で起こるようだ(47)。

T. brucei膜(48)で $\mathrm{Man}_{3}$-GlcN-PIを作るため、in vitroでDol-P$\left[{ }^{3} \mathrm{H}\right] \mathrm{Man}$ がGPIプレカーサーに結合したときの細胞質のホスホリ パーゼCに対する感受性から、GPIの中間体は細胞質側のER膜に 局在されていることがわかる。EtN-phospho-Man ${ }_{3}$-GlcN-PIはま た、T. brucei (48)ではER膜の細胞質側にみられる。完全に合成 されたGPIは、ERの内腔へflip-flopされ、そこでタンパク質へ転 移する。その時GPIトランスアミダーゼ(PGTase)が、GPIがタン パク質へ付加するのを触媒する(49-51)。 
Trends in Glycoscience and Glycotechnology Vol.10 No.56 (November 1998) pp.439-453

Compartmentalization of GPI biosynthetic pathways is of interest where more than one type of GPI is found in a cell. Leishmania for example contains polysaccharide GPIs, protein GPIs and GIPLs. The in vivo sensitivity of GPI precursors to stably expressed T. brucei GPI-PLC has been used to study the compartmentalization of protein and polysaccharide-GPI biosynthesis in Leishmania $(52,53)$. GPI-PLC is localized to the cytoplasmic side of intracellular membranes where it might cleave the GPI precursors if they co-localize with the enzyme. Reduced surface expression of GPI anchored proteins in GPIPLC expressing Leishmania suggested that protein-GPI biosynthesis occurs on cytosolic side of the ER. Polysaccharide-GPIs were not depleted by the enzyme, indicating lumenal topology of LPG biosynthesis $(52,53)$. In agreement with this proposal, LPG1 gene product involved in LPG biosynthesis is oriented lumenally (54).

A number of genes encoding enzymes involved in GPI biosynthesis have been cloned by complementation of the mammalian and yeast mutants. These genes include $P I G-\mathrm{A}, P I G$-B, $P I G$-C, $P I G$-F, $P I G$-H, $P I G$-L from mammalian cells and $G P I 1$, GPI2, GPI3/SPT14, GAA1, GPI8 genes from yeast (55-63). Three gene products are required for the first biosynthetic step in both mammalian cells (PIGA, PIGC and PIGH) and yeast (gpil, gpi2, gpi3). PIGL is required for conversion of GlcNAcPI to GlcN-PI. Accumulation of mature GPI-precursors which do not attach to proteins in GPI8 defective T lymphoma cells $(51,64,65)$ or yeast mutants $(50))$ and $G A A 1$ defective yeast mutants (58) indicate a role of these gene products in GPI addition to protein.

The predicted properties of the polypeptides encoded by GPI biosynthetic genes confirm the cytoplasmic orientation of these reactions. PIG-A, PIG-C, PIG-H, and PIG-L encode proteins that lack a signal peptide for translocation in the ER lumen. Some of the encoded proteins have also been localized to cytosolic membranes $(57,60,66,67)$.

GPI lipid remodeling may take place either before or after attachment to the protein. Such remodeling is well documented in T. brucei $(68)$, T. cruzi $(30,69)$ Leishmania $(70)$ and yeast (71-73). Two types of lipid modifications have been described in kinetoplastids: remodeling and denovo exchange. Remodeling of GPI precursors before attachment to proteins, as documented in $T$. brucei involves sequential replacement of fatty acids at sn- 2 and sn- 1 position with myristic acid (68). Replacement of alkyl-acyl moiety with ceramide on $\mathrm{Man}_{3-4}-\mathrm{GlcN}$ PI provides precursors for LPPG biosynthesis in T. cruzi (16). A process similar to fatty acid remodeling i.e. fatty acid exchange is also described in trypanosomes. VSG attached GPI has been suggested to undergo a regular exchange of myristate with myristate donated by myristoyl- $\mathrm{CoA}(74,75)$. Though process of myristate exchange and lipid remodeling is suggested to occur in different compartents, functional significance of the fatty
1種類以上のGPIが細胞内で見られる点で、GPI生合成経路の 局在の仕方は興味深い。例えば、Leishmaniaは多糖GPI、タンパ ク質GPI、そしてGIPLを含む。常に存在する $T$. brucei GPI-PLCに 対するのGPIプレカーサーのin vivoでの感受性は、Leishmania (52、53)でのタンパクの分類と多糖GPI生合成を研究するのに使 われてきた。GPI-PLCは、細胞内膜の細胞質側に位置し、もし GPIプレカーサーが酵素と一緒にあればそれを分解する。GPIPLCを発現しているLeishmaniaでGPIアンカータンパク質の表面 発現が減っていることは、タンパクGPI生合成が、ERの細胞質 の細胞質側で起こることを示唆する。多糖GPIは䤉素によって量 的に低下しないことから、LPG生合成(52、53)は内腔に位置して いることを示している。LPG生合成に関与しているLPG1遺伝子 産物は、内腔に配向しているという事実が、この考えを裏付け ている(54)。

GPI生合成に関与する酵素をコードしている多くの遺伝子 は、哺乳類とyeast 変異株の相補性を用いてクローン化された。 これらの遺伝子には哺乳類細胞からの、PIG-A、PIG-B、PIGC、PIG-F、PIG-H、PIG-Lが含まれyeastからのGPI1、GPI2、 GPI3/SPT14、GAA1、GPI8遺伝子が含まれる(55-63)。3つの遺伝 子産物は、哺乳類細胞(PIG-A、PIG-C、PIG-H) とYeast (gpi1、 gpi2、gpi3)の両方において最初の生合成ステップで必要であ る。PIG-Lは、GlcNAc-PIから GlcN-PI へ変換するのに必要であ る。GPI8が欠損したTリンパ腫細胞(51、64、65)、GAA1が欠損 したyeast 変異株(58)で、タンパク質についていない成熟型GPIプ レカーサーがたまるのは、これら遺伝子産物の役割がGPIをタン パク質へ付加することであるとわかる。

GPI生合成遺伝子がコードするポリペプチドの予想された性 状により、これらの反応が細胞質側に存在することが確認され る。PIG-A、PIG-C、PIG-H、PIG-Lは、小胞体内腔で転移に必要 なシグナルペプチドを持たないタンパク質をコードしている。 コードされるタンパク質のいくつかは、細胞質膜に局在してい る(57、60、66、67)。

GPIの脂質のリモデリングは、タンパク質につく前か後のど ちらかで起こるようだ。そういったリモデリングは、T. brucei (68)、T. cruzi (30、69)、Leishmania (70)、yeast (71-73)で十分 証明されている。2種類の脂質修飾りモデリングとde novo交換 が、 kinetoplastidで述べられてきた。T. bruceiで証明されるよう にタンパク質につく前のGPIプレカーサーのリモデリングは、 sn-1 とsn-2位で脂肪酸がミリスチン酸へ、連続して置換する (68)。 $\mathrm{Man}_{3-4}$-GlcN-PIでのアルキルアシル部のセラミドへの置換 より、T. cruzi(16)でLPPGでの生合成のプレカーサーができる (16)。脂肪酸リモデリングすなわち脂肪酸交換に類似したプロセ スが、Trypanosomeでもまた述べられている。GPIの付いたVSG は、ミリストイル-CoA (74、75)により供給されるミリストイル 酸でミリストイル交換を受けると言われてきた。ミリストイル 交換と脂質りモデリングのプロセスは、異なったコンパートメ ントでおこるといわれているけれども、脂肪酸交換が機能的に 
acid exchange remains unknown.

Despite the similarity in the GPI biosynthetic pathway in various organisms, several unique features have been observed in mammalian cells as compared to protozoans (Fig. 1). For example, acyl-CoA dependent acylation of the inositol ring to produce GlcN-(acyl)PI is obligatory before mannosylation can proceed in yeast and rodent cells $(45,72,76,77)$. Inositol acylation is not a pre-requisite for mannosyl or EtNP transferases of protozoans $(41,78)$. Thus, mannosyl transferase(s) of T. brucei may have different substrate specificity than the enzymes catalyzing a similar function in yeast and mammalian cells. The enzymes responsible for inositol acylation and deacylation in $T$. bruce $i$ are sensitive to phenylmethylsulfonyl fluoride (PMSF) and diisopropylfluorophosphate (DFP) respectively (79), whereas enzymes with similar activity in mammalian cells are unaffected (80). Mature free GPIs with acylated inositols though absent in Leishmania (41) and P. falciparum (17) are present in abundance in $T$. brucei $(78,81)$ and $T$. gondii $(82)$. However, transfer of these mature, inositol-palmitoylated GPIs to proteins as documented in mammalian cells $(76,83)$ and yeast $(73)$ remain undetected in protozoans.

Identification of natural or synthetic molecules differentially recognized by the GPI biosynthetic machinery of yeast and mammalian cells or protozoans $(84,85)$ confirms the fact that GPI biosynthetic pathway is significantly different between protozoans and higher eukaryotes. This presents the possibility of utilizing GPI-biosynthesis as a target for anti-protozoan chemotherapy. Acquisition of detailed information on biochemical and structural properties of GPI biosynthetic enzymes may provide knowledge for rational design of chemotherapeutic agents capable of specifically blocking the growth of the pathogenic protozoans.

\section{Functional Importance of GPIs}

Proteins which are attached to GPI anchors include hydrolases, signal transducers, receptors, ligands, cell adhesion molecules and coat proteins, i.e. they vary extensively in their function. In addition, free GPIs or polysaccharide-GPIs of protozoans may have roles in parasite growth, virulence and survival. Detailed discussion of the function of GPIs in mammalian cells is presented in some recent reviews $(7,86)$. In this review, I will focus on the function of GPIs in protozoan parasites (Tables I, II).

\section{D-1. Attachment to, Invasion of, and Survival in Mamma lian Hosts}

GPI anchored macromolecules play important roles in the survival of protozoan parasites in mammalian cells. In Leishmania, gp63 and LPG have been recognized as virulence factors. Leishmania promastigotes deficient in gp63 exhibit reduced infectivity of macrophages in vitro $(87,88)$ as well as in vivo $(89,90)$. GP63 is proposed to enable the promastigotes to
どう重要であるかはわかっていない。

さまざまな生物でGPI生合成経路は似ているにもかかわら ず、原生動物と比較して哺乳類細胞では、いくつかの際だった 特徵が見つかった(図1)。GlcN-acyl-PIを合成するためのイノシ トール環でのacyl-CoA依存性アシル化は、yeast、栔歯動物細胞 でマンノシル化が起こる前には必須の過程である(45、72、76、 77)。一方イノシトールアシル化は、原生動物のマンノシルある いはEtNPトランスフェラーゼにとっては必須のものではない (41、78)。従って、T. bruceiのマンノシルトランスフェラーゼは yeast と哺乳類細胞において、類似した機能を触媒する酵素であ るが、異なった基質特異性を持つのかも知れない。

T. bruceiのイノシトールアシル化と脱アシル化の原因である 酵素は、フェニルメチルスルホニルフルオリド(PMSF)とジイソ プロピルフルオロフォスフェイト(DFP)のそれぞれに感受性であ る一方で、哺乳類細胞での類似した活性をもつ酵素は影響を受 けない。アシル化されたイノシトールを持つフリーな成熟型GPI は、Leishmania (41)、P. faluciparum (17)にはないけれどもT. brucei $(71 、 81)$ と T. gondii (82)に豊富に存在する。これらの成熟 型イノシトールパルミトイル化GPIが、タンパク質へ転移すると いうのは哺乳類細胞とyeastで証明されている。しかしながら、 原生動物では見つけられていない。

yeast、哺乳類細胞、原生動物(84、85)のGPI生合成機構によ り、天然や合成の分子が異なって認識されることで、GPI生合成 経路は原生動物と高等な真核生物の間では大きくに異なること が確かめられている。このことは、原生動物に対する化学療法 のターゲットとしてGPI生合成を利用できることを示す。GPI生 合成酵素の生化学的、構造的特性に関する詳しい情報を得るこ とで、病原性を持つ原生動物の成長を特異的に止めるのに利用 できる化学療法試薬を、合理的にデザインできる知識を与える 可能性がある。

\section{GPIの機能的重要性}

GPI アンカー化されているタンパク質には、ハイドロラー ゼ、シグナルトランスヂューサー、リセプター、リガンド、細 胞付着分子、コートタンパク質などがある。言ってみれば、そ れらは、機能的に大きく異なっている。加えて原生動物のフ リーなGPIや、多糖GPI、寄生虫の成長、毒性、生存において 役割をもつかも知れない。哺乳類細胞でのGPIの機能は、いくつ かの最近の論文で述べられている(7、86)ので、この論文では、 原生動物寄生虫でのGPIの機能を中心に述べる(表I、II)。

\section{D-1. 哺乳類宿主への接着、進入、生存}

GPIアンカーのマクロ分子は、哺乳類細胞において原生動物 の寄生虫が生存するのに重要な役割を果たす。Leishmaniaにおい て、gp63、LPGはvirulence因子と考えられていた。Leishmania promastigoteでのgp63欠損は、in vivo(89、90)だけでなく、in vitro (87、88)でもマクロファージの感染性を下げる。GP63は、 
Trends in Glycoscience and Glycotechnology

Vol.10 No.56 (November 1998) pp.439-453

Table I. Some of the GPI-anchored proteins in parastic protozoans.

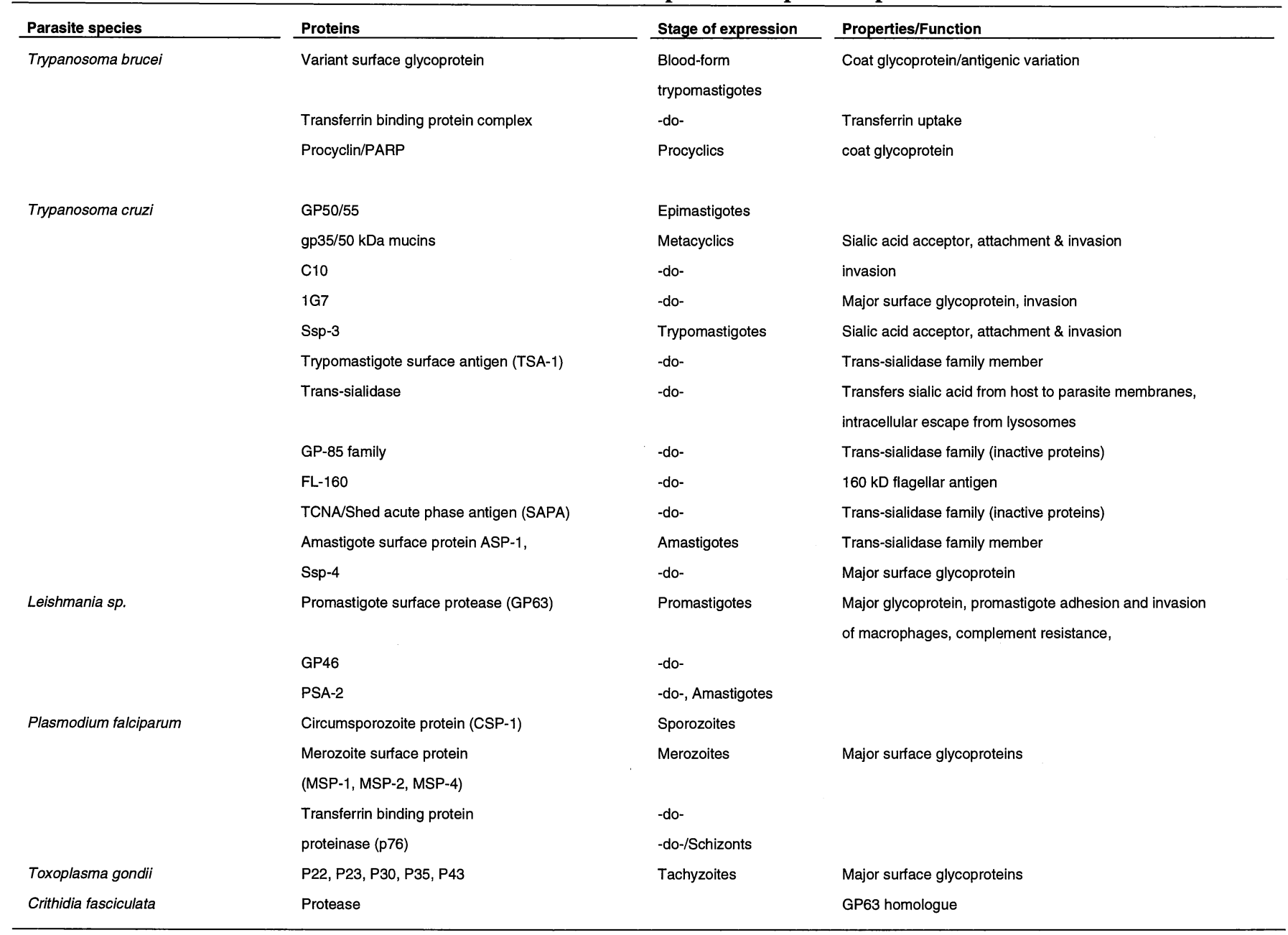

withstand complement mediated lysis (90). GP63 promotes the binding of promastigotes to macrophage by its direct interaction with macrophage complement receptor type 3, Mac-1 (91, 92) and the fibronectin receptor (93). In addition, gp63 is the primary acceptor for $\mathrm{C} 3$ deposition (94). Proteolytic conversion of surface bound C3b, by gp63 to iC $3 b(95,96)$ which is a better ligand for Mac-1 promotes parasite adhesion to and invasion of macrophages (97).

The major surface glyco-conjugate of Leishmania, LPG, facilitates promastigote attachment to the midgut of the sand fly insect vector $(98,99)$. LPG is modified during metacyclogenesis (the maturation of non-infective promastigotes to infective metacyclic promastigotes) by capping of terminal $\beta$-gal residues and elongation of the phospho-disaccharide (PO4-6Gal( $\beta 1$ 4) Man( $(\alpha 1-))$ repeats (100). This modified LPG serves as a ligand for attachment of metacyclics to host macrophages. The receptor binding domain of LPG is the phospho-disaccharide repeat $(99,101)$. LPG also contributes to provide resistance to complement mediated lysis of metacyclics $(102,103)$. LPG deficient Leishmania promastigotes exhibit reduced virulence $(104,105)$ promastigoteが補体による分解に抵抗できるようにすると言われ る。GP63は、マクロファージ補体リセプターtype3、Mac-1 (91、 92)やフィブロネクチンリセプター(93) と直接に相互作用するこ とで、 promastigoteがマクロファージへ結合するのを促進する。 加えて、gp63は、C3沈着の最初のアクセプターである(94)。そ してgp63が、細胞表面に結合したC3bをタンパク分解により変換 することで、Mac-1よりよいリガンドであるiC3b (95、96)を作り だし、寄生虫の接着とマクロファージへの侵入を促進する(97)。

Leishmaniaの重要な表面多糖体であるLPGは、promastigote が媒介昆虫である sand flyの中腸にくっつくのを促進する(98、 99)。LPGは、 metacyclogenesis (非感染性promastigoteから感染性 metacyclic promastigoteへの成熟過程のこと)の間に末端 $\beta$-gal残基 のキャッピングとホスホジサッカライド(PO4-6Gal( $\beta$ 1-4)Man( $\alpha$ 1-))の繰り返し(100)の伸長によって修飾される。この修飾LPG は、宿主マクロファージに対する metacyclicの結合のリガンドと して役立つ。LPGのリ七プター結合ドメインは、ホスホジサッ カライドの繰り返し(99、101)部である。LPGは、また補体によ る metacyclicの溶解に抵抗するのに役立つ(102、103)。LPG欠損 Leishmania promastigoteは、virulencyが減少している(104、105)。 
Table II. Function of glycosylphosphatidylinositols in parasitic protozoans.

\begin{tabular}{lll}
\hline \multicolumn{1}{c}{ Function } & Parasite species & GPI molecule \\
\hline Promastigote adhesion and invasion of macrophages & Leishmania & LPG \\
Metacyclics adhesion to macrophages & Leishmania & LPG \\
Surface glycocalyx lateral mobility & T. brucei & VSG-GPI \\
Complement resistance & Leishmania & LPG, GIPL, \\
& T. brucei & VSG-GPI, PARP-GPI \\
Activation of macrophages, cytokines secretion and & $T$. brucei, P. falciparum & GPI \\
iNOS synthesis & T. cruzi & trypomastigote-mucin-GPI \\
Activation of protein tyrosine kinase & T. brucei, P. falciparum, Leishmania & GPI \\
Activation of protein kinase C & T. brucei, T. cruzi, P. falciparum & GPI \\
Inhibition of macrophage function, iNOS synthesis & Leishmania & GIPLs, LPG \\
Inhibition of protein kinase C & Leishmania & LPG, GIPL \\
Growth and replication & T. cruzi, & GPI \\
& Leishmania & GIPL \\
Virulence & T. cruzi & GPI \\
& Leishmania & GIPL \\
\hline
\end{tabular}

which could be partially regained by ex vivo treatment with LPG (106) or LPG complementation (107). LPG mutants of L. major (with 10-fold reduced expression of LPG), compared to wildtype parasites, are avirulent in mice (108).

Several different, predominantly stage specific GPI-anchored proteins are reported to be involved in attachment, invasion and intracellular escape of T. cruzi. Examples include 1G7 (gp90) (109), gp82 (110) and 35/50 kDa mucins $(111,112)$ of metacyclic trypomastigotes, Ssp-3 (113), gp-85 (114) of bloodform trypomastigotes and possibly Ssp-4 of amastigotes (115). Pre-treatment of metacyclics with anti-1G7 (116) or anti-gp35/ $50(111,117)$ antibodies or trypomastigotes with anti-Ssp-3 $(118$, $119)$ or anti-Tc85 $(114,120)$ antibodies inhibits invasion in vitro and neutralizes infection in mice. One interpretation of these data is that multiple T. cruzi ligands are involved during establishment of an infection. Nevertheless, verification of these observations awaits genetic studies.

Sialylation of parasite GPI anchored proteins might be important for invasion of host cells by T. cruzi. Transfer of sialic acid from host donor molecules to T. cruzi $35 / 50 \mathrm{kDa}$ mucins (121) and Ssp-3 (122) is catalyzed by a trans-sialidase which is itself GPI anchored. Sialylation of parasite surface molecules appears to correlate with the invasive capability of $T$. cruzi, as removal of sialic acid from mammalian cells with glycosidases (123), masking of surface carbohydrate moieties of fibroblasts (124), or the use of sialic acid deficient mutant Lec-2 cells (125, 126) results in a reduction in invasion by T. cruzi. However, the lack of complete blockage of invasion in the above mentioned experimental models and in a GPI deficient isolate of $T$. cruzi (127) suggest that non-sialylated ligands might also be important in attachment and invasion of T. cruzi.

The binding of $T$. cruzi trypomastigotes to host cells is
それは、外からLPG (106)を処理したり、LPGを補うことにより 回復する(107)。L. major のLPG 変異株(LPGの発現が10分の1に 減っている)は wild typeの寄生虫と比較して、ねずみに対しvirulentではない(108)。

いくつかの異なった stage 特異的GPIアンカータンパク質 は、T. cruziの接着、侵入、細胞内逃避に必要とされている。こ れらの例としてmetacyclic trypomastigoteの1G7(gp90) (109)、gp82 (110)、35/50kDa ムチン $(111 、 112) 、$ 血流型 trypomastigote のSsp3 (113)、gp85 (114)、amastigote の Ssp-4 (115)が含まれている。 抗1G7(116)や抗 gp35/50 抗体(111、117)でmetacyclicを前処理し たり、抗Ssp-3(118、119)、抗Tc85(114、120)抗体で trymastigote を処理すると、ねずみで、in vitroでの侵入を阻害し、感染を中 和する。これらのデー夕に対する1つの説明として、感染成立中 には複数のT. cruzi リガンドが関与していることがあげられる。 しかし、これらの結果の確認には遺伝的研究が必要である。

寄生虫GPIアンカータンパク質のシアル酸化は、T. cruziが宿 主細胞に侵入するのに重要であろう。宿主ドナー分子から、T. cruzi 35/50kDaのムチン(121) とSsp-3 (122)へシアル酸を転移する のは、GPIアンカー化されたシアル酸転移酵素により触媒され る。グリコシダーゼにより哺乳類細胞からのシアル酸の除去 (123)、フィブロプラストの表面の炭水化物部分のマスキング (124)、シアル酸欠損変異株のLec-2 cell (125、126)の使用は、 $T$. cruziが、侵入するのを結果的に減らすので、寄生虫表面分子の シアル酸化は、T. cruziの侵入に関連しているようだ。しかしな がら、上で述べた、実験モデルとT. cruzi (127)の単離したGPI欠 損株において、侵入を完全にブロックできないのは、シアル酸 化されていないリガンドもまた、T. cruziの接着と侵入において 重要である可能性を示唆している。

T. cruzi trypomastigoteの宿主細胞への結合に続いて、寄生虫 
followed by $\mathrm{Ca}^{+2}$ influx and the gradual fusion of host lysosomes with plasma membrane at the site of parasite attachment. Lysosomal fusion provides the membrane required for parasite entry and vacuole formation (128-130). The trypomastigote stage 120-kDa peptidase (115) and metacyclic stage mucin-like GPI-anchored proteins C10 (131) and gp35/50 (112) have been proposed to initiate $\mathrm{Ca}^{+2}$ flux and probably lysosome clustering through different mechanisms. Once inside the lysosomal vacuole, removal of sialic acid from the lysosomal membrane by $T$. cruzi trans-sialidase glycoprotein facilitates vacuole disruption by a hemolysin like molecule and release of $T$. cruzi into the host cell cytoplasm. At the same time, parasites protect themselves from the hydrolytic enzymes of lysosome by sialylation of their own surface via trans-sialidase reaction $(132,133)$.

In African trypanosomes, VSG is the major coat protein. Densely packed VSG dimers and $\alpha$-galactosyl chains of the GPI anchor $(134,135)$ occupy most of the cell surface of the bloodstream form trypomastigotes. VSG-GPI has been proposed to provide lateral mobility to the protein and assist in the creation of a macromolecular diffusion barrier by close packaging of its galactosyl side chain to the parasite plasma membrane $(4,136)$. This arrangement of VSG might minimize the access of host defense proteins (e.g. antibodies) to underlying antigens on the parasite plasma membrane $(4,136)$. VSG itself is highly immunogenic, however the T. brucei population survives the host immune responses by antigenic variation wherein the coat protein is regularly replaced by a different VSG (137). .

The surface of procyclic stages of T. bruce $i$ is dominated by PARP. The PARP-GPI anchor has a complex side chain containing $\mathrm{N}$-acetylglucosamine, glucose and sialic acid residue (138) which might also contribute to formation of a dense protective glycocalyx for the insect stage of the parasite. Sialylation of PARP-GPIs contribute to prevention of lysis of T. brucei procyclics exposed to complement in insect blood-meal (139).

\section{D-2. Growth and Replication}

The abundance of GPIs in kinetoplastid parasites and the variety of biological roles assigned to them suggests that the ability to make GPIs might be critical for the growth and survival of these organisms. This hypothesis is confirmed by the fact that GPI depletion correlates with a growth deficiency in both Leishmania and T. cruzi (52, 53, 140, Mensa-Wilmot and Garg et al. 1998, submitted). The intracellular amastigote stage of these protozoans was especially sensitive to a GPI deficiency. GPI deficient $T$. cruzi amastigotes displayed several phenotypes; including limited replication, lack of differentiation to trypomastigotes, and duplication of the kinetoplast but failure to replicate the cell nucleus $(127,140)$.

GPI deficient $T$. cruzi and Leishmania are less virulent in animal models of Chagas' disease and Leishmaniasis (140, Mensa-Wilmot and Garg et al. submitted). Thus, GPIs appear to be necessary for maintaining the viability and/or replication
接着部での $\mathrm{Ca}^{2+}$ 流入と、血漿膜と宿主リソゾームとのゆっくり とした融合が起こる。リソゾーム融合が寄生虫侵入と小腔形成 (128-130)に必要となる膜を供給する。trypomastigote stage120$\mathrm{kDa}$ ペプチダーゼ(115)、metacyclic stage ムチン様GPIアンカータ ンパク質C10 (131)、gp35/50 (112)は、 $\mathrm{Ca}^{2+2}$ 流動とリソゾームのク ラスターリングを異なったメカニズムで起こすと言われてい る。いったんリソゾームの小胞に入ったら、T. cruzi transsialydase糖タンパク質が、リソゾーム膜からシアル酸を除去する ことで、hemolysin様分子が小胞破壊を促進し、T. cruziを宿主の 細胞質へ放出するのを容易にする。同時に、寄生虫は、シアル 酸転移酵素反応によって表面をシアル酸化することで、リソ ゾームの加水分解酵素より自分を守る(132、133)。

African trypanosomeにおいて、VSGは主なコートタンパク質 である。GPIアンカー(134、135)のぎっしりつまったVSG 二量体 と $\alpha$-ガラクトシル鎖は、血流型trypomastigoteの細胞表面のほと んどをしめる。VSG-GPIは、タンパク質に膜上での横の動きを 与え、寄生虫原形質膜をガラクトシル側鎖で閉じこめることに より、マクロ分子拡散バリアーの形成を助ける(4、136)。この VSGの配列は、寄生虫の原形質膜の下に存在する抗原に、宿主 防御タンパク質(抗体)が接近するのを最小にする(4、136)。VSG はそれ自体高い免疫原性を持つ。しかしながら、T. brucei集団 は、抗原変化により宿主免疫反応から逃れ、そこで異なった VSGがコートタンパクにとってかわる(137)。

T. bruceiのprocyclic stageの表面は、PARPがしめている。 PARP-GPIアンカーは、N-アセチルグルコサミン、グルコース、 シアル酸残基を含む複雑な側鎖を持つ(138)。それは、insect stageの寄生虫にとって密集した保護的糖衣を形成するのに役立 つかも知れない。PARP-GPIのシアル酸化は、昆虫 blood meal中 の補体により、T. brucei procyclicが溶解するのを防止するのに役 立つ(139)。

\section{D-2. 成長と複製}

kinetoplastidの寄生虫で、GPIが豊富であることと、それら に割り当てられているさまざまな生化学的役割から、GPIをつく るのは、これらの生物の成長と生存には重要であることがわか る。GPIの枯渴が、LeishmaniaとT. cruzi (52、53、140 MensaWilmont\&Gargら 1998に提起した)で、成長における久損と 関連しているという事実により、この仮説が確かめられた。こ れらの原生動物の細胞内の amastigote stageはGPI 欠損に特に感受 性である。GPI欠損T. cruzi amastigoteは、いくつかの表現型をし めしている。例えば、複製ができないもの、trypomastigoteへの 分化ができないもの、kinetoplastidの複製はできるが、細胞核の 複製はできないものなどがある(127、140)。

GPI欠損のT. cruziとLeishmaniaは、シャガス病とリーシュマ ニア症の動物モデルにおいて、ほとんどvirulentでない(140、 Mensa-Wilmot\&Gargら提起した)。このことからGPIは、これら 寄生性原生動物の生存能力と複製を維持するのに必要であるよ 
of these parasitic protozoans. These results have important implications for the treatment and prevention of infection with these protozoans: (i) Enzymes in the GPI biosynthesis pathway could be excellent targets for chemotherapeutic interventions; (ii) Protozoans with mutations in the GPI biosynthetic pathway may have utility as "live" vaccines.

\section{D-3. Effect of Protozoan Parasite GPIs on Host Cells}

Mammalian hosts frequently respond to the entry of infectious agents by activation of non-specific acute responses. The stimuli provided by foreign molecules (e.g. bacterial lipopolysaccharides, carbohydrates, DNA etc.) initiate the activation of macrophages which is primed by interferon- $\gamma$ (IFN- $\gamma$ ) produced by natural killer (NK) or T cells. Activated macrophages produce tumor necrosis factor (TNF- $\alpha$ ) and interleukin-12 (IL-12), which act in synergy to stimulate inducible nitric oxide synthase (iNOS) synthesis. iNOS activation results in production of high levels of nitric oxide (NO), which is a major effector molecule against intracellular pathogens $(141,142)$. In the case of protozoan infections, GPIs and GPI anchored proteins may provide signals for macrophage activation, cytokine release and NO production.

In T. cruzi infection, host macrophage function is important in the control of extra-cellular trypomastigotes. Trypomastigote mucin-GPIs are suggested to be the potent inducers of IFN- $\gamma$ dependent macrophage activation and of proinflammatory cytokines (TNF- $\alpha$ and IL-12) (143) and NO synthesis by activated macrophages (144). Both the glycan as well as the lipid moieties of the trypomastigote mucin-GPIs contribute to macrophage activation and cytokine secretion. Epimastigote or metacyclic mucin-GPIs do not activate macrophages, suggesting that stage specific differences in GPI structure influence the activity of the glycolipids (143).

Malarial parasite and African trypanosome GPIs also induce macrophage and endothelial cell activation and trigger cytokine and NO synthesis $(86,145-147)$. The phosphoglycan fraction of Leishmania LPG has also been shown to induce NO and TNF- $\alpha$ production (148).

In contrast to above examples, GPI anchored macromolecules may also be employed by the protozoans to inhibit macrophage activation. Leishmania GIPLs and LPGs inhibit IFN- $\gamma$ dependent macrophage activation, iNOS synthesis and NO output (149-151). A majority of the inhibitory effect is found in the alkylacylglycerol moiety of the GPIs (152). It thus appears that LPGs and GIPLs are utilized by Leishmania to regulate the expression of iNOS and the leishmanocidal activity of macrophages, thereby promoting the parasite survival.

The activation of protein tyrosine kinase (PTK) is a key signalling step in the regulation of numerous cellular responses including lymphocyte and macrophage activation. Protozoan GPIs are proposed to exert their effect by regulating the PTK mediated activation of lymphocyte and macrophage immune
うに見える。これらの結果は、こういった原生動物の取り扱い や、感染に対しての防御に重要な意味をもっている。つまりGPI 生合成経路に関与する酵素は、化学療法にとって、すばらしい ターゲットとなりうる。またGPI生合成経路において変異を持つ 原生動物は、生きたワクチンとして有用性をもつかもしれな い。

\section{D-3. 宿主細胞上での原生動物寄生虫の効果}

哺乳類宿主は、非特異的な急性反応を活性化することによ り感染性病原体の侵入に反応する。異物(例えば、細菌性のリポ サッカライド、炭水化物、DNAなど)により刺激を与えると、ナ チュラルキラー(NK)やT細胞により作られるINF $\gamma$ によってマク ロファージの活性化が開始される。活性化したマクロファージ は、腫瘍壊死因子(TNF- $\alpha$ )とインターロイキン12(IL-12)を作り、 それは誘導NOシンターゼ(iNOS)合成を刺激する際に共同作用す る。iNOS活性化は、結果的に一酸化窒素(NO)の高レベル産生へ とつながり、それは細胞内病原体に対し、主要なエフェクター 分子である(141、142)。原生動物の感染の際、GPIとGPIアンカー タンパク質は、マクロファージ活性化、サイトカイン放出、NO 産生に対するシグナルを与える可能性もある。

T. cruzi感染において、宿主マクロファージ機能は、細胞外 のtrypomastigoteのコントロールに重要である。trypomastigoteム チンGPIは、マクロファージ活性化依存性INF $\gamma$ 、前炎症性サイ トカイン(TNF- $\alpha$ とIL-12) (143)、活性化マクロファージ(144)によ るNO合成の誘発因子である可能性もある。trypomastigote ムチン GPIの脂質部分だけでなく、グリカンの両方がマクロファージ活 性化とサイトカイン分泌に役立つ。Epimastigoteやmetacyclicムチ ンGPIは、マクロファージを活性化しない。GPI構造での、stage 特異的相違が糖脂質の活性化に影響を与えると考えられている (143)。

マラリア寄生虫とAfrican trypanosome GPIは、マクロファー ジや内皮細胞の活性化、サイトカインを誘発しNOを合成する (86、145-147)。Leishmania LPGのphosphoglycan 分画は、NOと TNF- $\alpha$ 産生を引き起こすことが示されてきた。

上の例と反対に、GPIアンカーマクロ分子は、原生動物によ りマクロファージ活性化を阻害するためにも利用される。Leishmania GIPLとLPGは、マクロファージ活性依存性INF $\gamma$ 、iNOS生 合成とNO産生を阻害する(149-151)。大部分の阻害効果が、GPI のアルキルアシルグリセロール部分で見られる。LPGとGIPL は、iNOSの発現、マクロファージのleishmanosidal活性を調節す るためにLeishmaniaによって利用されるようだ。それゆえ、寄生 虫の生存を助ける。

プロテインチロシンキナーゼ(PTK)の活性化は、リンパ球と マクロファージ活性化を含む多くの細胞反応の調節をする上で かぎとなるシグナルステップである。原生動物GPIは、PTKが媒 介したリンパ球とマクロファージの免疫機能活性化を調節する 
Trends in Glycoscience and Glycotechnology Vol.10 No.56 (November 1998) pp.439-453

functions. Purified GPIs from P. falciparum, T. brucei and $L$. major induce rapid activation of PTK in murine macrophages and in human vascular endothelial cells $(86,147,152)$. The minimal structure required for PTK activation is $\mathrm{Man}_{3}$-GlcN-Insphospho-lipid $(86,152)$. However, PTK activation by $\mathrm{Man}_{3}$ GlcN-Ins-phospho-lipid is not sufficient for induction of TNF$\alpha$ and IL- $1 ß$ expression, suggesting the requirement for another signaling in order for cytokines expression and macrophage activation to occur. The sn-1,2 diacylglycerol (DAG) of $P$. falciparum and T. brucei GPIs activate the $\mathrm{Ca}^{+2}$ independent $\varepsilon$ isoform of mammalian protein kinase C (PKC) (147). Activation of both PTK and PKC by P. falciparum and T. brucei GPIs in synergy with IFN- $\gamma$ leads to induction of iNOS and TNF- $\alpha$ $(146,147,153)$.

GPIs from LPG and GIPL of $L$. major regulate IFN- $\gamma$ inducible iNOS expression in macrophages (154) via $\mathrm{Ca}^{+2}$ chelation and inhibition of PKC activation $(152,155)$. However, translocation of PKC to plasma membrane in response to $\mathrm{Ca}^{+2}$ occurs normally in presence of LPG $(149,156)$. LPG, therefore might inhibit events downstream of PKC recruitment (157).

Parasite derived GPIs thus play a role in regulating the host defense mechanisms. In some instances, activation appears to be an outcome of the interaction of parasite GPIs with host cells. The physiological advantage of such activation of immune functions to the parasite is elusive at the moment, although it is reasonable to explain the phenomenon as a legitimate host defense response. Suppression of host defense mechanism as documented for Leishmania seems more advantageous to the parasite. Evidently, numerous differences in the structure of GPIs are responsible for the variable outcomes. Identification of host receptors for the parasite GPIs will be a major challenge for the future.

\section{E. Release of GPIs from Protozoan Parasites}

Action of parasite-derived GPIs on host cells would require release of the glycolipids from the parasite plasma membrane. In T. brucei blood-stream form trypomastigotes, an endogenous GPI-PLC is expressed. The localization of GPI-PLC protein on the cytoplasmic side of intracellular membranes (158) suggests that GPI-PLC is unlikely to participate in release of GPIs which modulate the host cell activity. GPI intermediates synthesized on the cytosolic side of the endoplasmic reticulum (ER) membrane could be accessible to the enzyme in vivo. It can be hypothesized that GPI precursors are either protected from degradation by control of GPI-PLC activity or excessive production of GPIs, so that even if co-localized, sufficient GPI precursors would escape from GPI-PLC to serve as anchors for VSG. GPI anchored proteins are also released during differentiation of some protozoan parasites. Shedding of VSG during differentiation of blood-stream form trypomastigotes to procyclics in vitro occurs via a proteolytic cleavage (159).
ことで、効果を発揮すると言われている。P. falciparum、T brucei、L. majorから精製したGPIは、ねずみのマクロファージ、 人の血管内皮細胞での早いPTK活性化を誘導する(86、147、 152)。PTK活性化に必要な最小限の構造は、Man ${ }_{3}$-GlcN-Insphospo-lipidである(86、152)。しかし、この $\mathrm{Man}_{3}$-GlcN-Insphospo-lipidによるPTK活性は、TNF- $\alpha$ 、I- $\beta$ の発現の誘導には 十分ではない。サイトカイン発現とマクロファージ活性化を起 こすために、別のシグナルが必要であることを示唆する。P. falciparum、T. brucei のGPIのsn-1,2ジアシルグリセロール(DAG) は、哺乳類のCa ${ }^{2+}$ 非依存性プロテインキナーゼ $\mathrm{C}(\mathrm{PKC}) \varepsilon$ 型を活 性化する。INF $\gamma$ との協同作用において、P. falciparum、T. brucei GPIによるPTK とPKCの活性化は、iNOS とTNF- $\alpha(146 、 147 、$ 153)の誘導へとつながる。

L. majorのLPGとGIPLからのGPIは、 $\mathrm{Ca}^{2+}$ キレート化とPKC 活性の阻害(152、155)を経てマクロファージ(154)でのINF $\gamma$ 誘導 型iNOS発現を調節する。C $\mathrm{Ca}^{2+}$ に反応してPKCが原形質膜に移る のは、LPGの存在下で普通に起こる(149、156)。LPGはそれゆ え、PKCの回復過程の後に起こる現象を阻害すると考えられる (157)。

このように寄生虫に由来するGPIは、宿主防御メカニズムを 調節する役割を果たす。いくつかの例で、活性化は宿主細胞と 寄生虫GPIの相互作用の結果である。寄生虫にとって、そのよう な免疫機能の活性化の生理的な利点は、ちょっとわかりにく い。けれども宿主防御反応として現象を説明するのに、道理に 合っている。Leishmaniaで証明されるように宿主防御メカニズム の調節は、寄生虫にとって、より都合がよいようだ。

明らかにGPI構造での大きな違いは、様々な結果の原因とな る。寄生虫GPIに対する宿主レセプターの同定は、将来の大きな 目標となろう。

\section{E. 原生動物の寄生虫からのGPI遊離}

宿主細胞での寄生虫誘導GPIの作用は、寄生虫原形質膜から 糖脂質の遊離を必要とする。T. brucei 血流型 trypomastigoteで は、内在性のGPI-PLCが発現している。細胞内膜の細胞質側に GPI-PLCタンパク質が局在化していることは(158)、宿主細胞活 性を調節するGPIを放出するのに、GPI-PLCは関与しそうもない ことを示唆している。in vivoでは、小胞体(ER)膜の細胞質側で 合成されたGPI中間体は、䤉素の作用をうける可能性がある。 GPI前駆体は、GPI-PLC活性のコントロールにより、またGPIの 過度の産生により、分解から保護されると仮定されている。そ してたとえ共存しても、GPI-PLCの処理のあとでもVSGにとっ てのアンカーとして働くために、十分な量のGPI前駆体が残るだ ろうと考えられる。GPIアンカータンパク質は、また、いくつか の原生動物寄生虫の分化の際に遊離される。in vitroでの血流型 trypomastigoteのprocyclicsへの分化の際にVSGの分解は、タンパ 
Whether a protease releases VSG during antigenic variation is unknown.

In T. cruzi, a role for phospholipase $\mathrm{C}$ in the release of GPI anchored proteins was proposed due to the detection of cross-reacting determinant (CRD) epitope on Ssp-4 released from amastigotes (160). GPI anchored proteins display CRD epitope after cleavage by a GPI-PLC (161). We have not detected any potent, membrane-associated GPI-PLC activity that could facilitate the release of GPI anchored proteins in T. cruzi (Garg et $a l$., in preparation). The general mechanism by which GPI anchored proteins are released from $T$. cruzi was studied by an examination of the biochemical properties of a soluble, $180 \mathrm{kDa}$ protein (2C2-BP) which bears an epitope detected by monoclonal antibody $2 \mathrm{C} 2$ on amastigote Ssp-4. Results from these studies on the mechanism of release of 2C2-BP do not favor a PLC-mediated process (Garg et al., in preparation). Also, in T. cruzi trypomastigotes, Tc-85 is shed with an intact GPI $(27,162)$. From these reports, it appears that release of GPI anchored proteins in $T$. cruzi may occur by different mechanisms. The GPIPLC endogenous to T. brucei has not been detected in Leishmania or T. cruzi. The current evidence favors protease-mediated release. The existence of proteases on the plasma membrane of T. cruzi (gp50/55, members of cruzipain family) (163-166) and Leishmania (gp63) (167) lends credence to this possibility. The fate of the peptidyl-GPIs that might be generated after proteolytic cleavage of the GPI-anchored proteins remain unclear.

\section{F. Conclusion}

Studies on GPIs have progressed rapidly since the structure of protein-GPI was solved a decade ago. In particular, several distinct features have emerged concerning the GPI biosynthetic pathway in protozoans and animal cells. Parasitic protozoans utilize GPIs as a major mode of surface protein anchorage, and are far more dependent on GPIs for their growth and survival than mammalian cells. Molecular cloning and understanding the function of the genes involved in GPI biosynthesis in protozoans might provide important insights on the molecular mechanisms which govern the growth and differentiation of protozoan parasites. Disruption of GPI biosynthesis by targeted deletion of genes may result in the development of avirulent mutants whose utility in vaccine development can then be explored. Characterization of the biochemical properties and structural analysis of GPI biosnthesis gene products will determine the specificity of the enzymes involved in GPI biosynthesis in protozoans and mammalian cells. If significantly different, molecules which inhibit the GPI biosynthesis in parasitic protozoans and prove detrimental to the parasites without affecting the host, would have utility in chemotherapeutic treatment of several parasitic protozoan infections. The importance of parasite GPIs as signal transducers, and the molecular mechanism of activation or suppression of host immune reactions by GPIs
ク質分解(159)経由で起こる。抗原が変化する間、VSGをプロテ アーゼが遊離するかどうかはわかっていない。

T. cruziでは、 amastigote (160)から遊離するSsp-4上のcross-reacting determination (CRD)のエピトープが確認された結果、GPI アンカータンパク質の遊離においてホスホリパーゼCが関与する と考えられた(160)。GPI-PLCによって分解した後、GPIアンカー タンパク質は、CRDエピトープを露出する(161)。しかし、T. cruziのGPIアンカータンパク質の遊離を促進できるいかなる膜に 結合したGPI-PLC活性をも、我々はみつけることができなかっ た。T.cruziからGPIアンカータンパク質が遊離される一般的メカ ニズムは、可溶性 $180 \mathrm{kDa}$ binding protein (2C2-BP)の生化学性質 を調べることによって研究されてきた。この $2 \mathrm{C} 2$ - B P は、 amastigote Ssp-4のモノクローナル抗体 $2 \mathrm{C} 2$ によって検出できるエ ピトープを持っている。2C2-BP遊離メカニズムのこれらの研究 の結果は、PLCの媒介過程(Garg ら) とは合致しない。また、T. cruzi trypomastigote、Tc-85は、完全なGPIで遊離される(27、 162)。これらの研究から、T. cruzi でのGPIアンカータンパク質 の遊離は異なったメカニズムで起こるかもしれない。T. bruceiに 内在的なGPI-PLCは、LeishmaniaやT. cruziでは見つからなかっ た。現在の証拠は、プロテアーゼによる遊離という考えに合致 している。T. cruzi (gp50/55.cruzipain 族のメンバー)とLeishmania (gp63) (167)の原形質膜上でのプロテアーゼの存在は、この可能 性をより確かなものとしている。GPIアンカータンパク質のタン パク質分解の後、発生するかしれないペプチジルGPIがどうなる かは、わからないままである。

\section{F. 結 論}

GPIに関する研究は、10年前タンパクGPIの構造が解明され て以来急速に進歩した。特に、いくつかの異なった特徵が、原 生動物と動物細胞におけるGPI生合成経路に関連して出現した。

寄生性原生動物は、主要な表面タンパク質アンカーとして GPIを利用する。そして、その成長と生存を、哺乳類細胞以上に GPIに依存している。原生動物でのGPI生合成に関与する分子ク ローニングと遺伝子機能の理解は、原生動物寄生虫の成長と分 化を制御する分子メカニズムに対して、重要な示唆を与えうる かもしれない。ターゲット遺伝子を削除することで、GPI生合成 を止めることにより、virulentでない変異株の開発につながる。 そして、それを用いてのワクチン開発の可能性が開ける。GPI生 合成の遺伝子産物の生化学的性質の解明と構造解析により、原 生動物と哺乳類細胞でのGPI生合成に関与する酵素の特異性を決 めることができる。もしかなり異なるなら、寄生虫原生動物に おいてGPI生合成を阻害する分子や、宿主に影響を与えることが なくかつ寄生虫に有効なproveは、いくつかの寄生虫原生動物感 染の化学療法治療において有用になろう。シグナル伝達として の寄生虫 GPIの重要性とGPIによる宿主免疫反応活性化、あるい は抑制の分子メカニズムについてはさらに調べる必要がある。 
needs to be explored. The GPIs may prove useful as synthetic agonists or antagonists to study the course of the acute and chronic phase of diseases caused by protozoan parasites. Finally, GPI anchored proteins which are shed during intracellular development of the infective protozoans have been suggested to be the prime source of peptides for recognition by parasite specific cytotoxic T cells (168). Three T. cruzi GPI anchored proteins which are expressed in infective and intracellular stages have been identified as potential targets for $\mathrm{CD}^{+}$CTLs from chronically infected mice or humans $(169,170)$. Since antiparasite CTL activity is the major effector mechanism in control of intracellular parasites, cloning and identification of genes encoding GPI anchored proteins of protozoan parasites which enter the MHC class I pathway of antigen processing and presentation, and serve as good CTL target molecules, is required to explore their possible utilization in the development of multicomponent protein or genetic vaccines against parasitic infections.

\section{Acknowledgements}

I am grateful to Drs. Rick L. Tarleton and Kojo MensaWilmot who introduced me to protozoan parasites biology. My thanks are also due to RLT for his immense support and helpful discussions and KM-W for his critical comments on the manuscript. NG was supported by a WHO/TDR grant 940352 and a Biotechnology grant from the University of Georgia Research Foundation.
原生動物寄生虫が原因である急性、慢性の疾患を研究するのに GPIは、合成アゴニストあるいはアンタゴニストとして役立つこ とが明らかになるだろう。感染性原生動物の細胞内の分化中に 脱ぎ捨てられるGPIアンカータンパク質は、寄生虫特異的細胞傷 害性T cell (168)による認識にとって、ペプチドの最も重要な sourceであると考えられている。感染性及び細胞内stageで発現す る3つのT. cruzi GPIアンカータンパク質は、慢性的に感染した ねずみと人(169、170)から、CD8+CTLにとって可能性のある ターゲットとして同定された(169、170)。原生動物に対するCTL 活性は、細胞内寄生虫のコントールにおいて主要なエフェク ターメカニズムなので、抗原のプロセシングや提示のMHCクラ スI経路に入る感染性原生動物のGPIアンカータンパク質をコー ドしている遺伝子の同定で、クローニングが、寄生虫感染に対 して、多成分タンパク、遺伝子ワクチンの開発における利用の 可能性を高める為に必要である。

\section{名古屋市立大学・薬学部・微生物薬品化学教室} 早川 潤 訳

\section{References}

1. Ferguson, M.A.J. (1994) Parasitology Today 10, 48-52

2. Ferguson, M.A.J. (1995) Methods in Enzymology 250, 614-630

3. Ferguson, M.A.J. (1997) Philos. Trans. R. Soc. Lond. B. Biol. Sci. 352, 1295-1302

4. McConville, M.J., and Ferguson, M.A.J. (1993) Biochem. J. 294, 305-324

5. Englund, P.T. (1993) Annu. Rev. Biochem. 62, 121-138

6. Schofield, L., and Tachado, S.D. (1996) Immunol.Cell Biol. 74, 555-563

7. Stevens, V.L. (1995) Biochem. J. 310 (Pt 2), 361-370

8. Udenfriend, S., and Kodukula, K. (1995) Annu. Rev. Biochem. 64, 563-591

9. Ferguson, M.A.J., Haldar, K., and Cross, G.A.M. (1985) J. Biol. Chem. 260, 4963-4968

10. Ferguson, M.A., Homans, S.W., Dwek, R. A., and Rademacher, T. W. (1988) Biochem. Soc. Trans. 16 (3), $265-268$

11. Murray, P.J., Spithill, T.W., and Handman, E. (1989) J. Immunol. 143 (12), 4221-4226

12. McConville, M.J., Thomas Oates, J.E., Ferguson, M.A., and Homans, S.W. (1990) J. Biol. Chem. 265, 19611-19623

13. Schneider, P., Ferguson, M.A., McConville, M.J., Mehlert, A., Homans, S.W., and Bordier, C. (1990) J. Biol. Chem. 265 (28), 16955-16964

14. Heise, N., Cardoso de Almeida, M.L., and Ferguson, M.A.J. (1995) Mol. Biochem. Parasitol. 70, 71-84

15. Serrano, A.A., Schenkman, S., Yoshida, N., Mehlert, A., Richardson, J.M., and Ferguson, M.A.J. (1995) J. Biol. Chem. 270 (45), 27244 27253

16. Heise, N., Raper, J., Buxbaum, L.U., Peranovich, T. M. S., and Cardoso de Almeida, M. L. (1996) J. Biol. Chem. 271, 16877-16887

17. Gerold, P., Dieckmann-Schuppert, A., and Schwarz, R.T. (1994) J. Biol. Chem. 269 (4), 2597-2606

18. Gerold, P., Schofield, L., Blackman, M., Holder, A., and Schwarz, R. (1996) Mol. Biochem. Parasitol. 75, 131-143

19. Tomavo, S., Dubremetz, J.F., and Schwarz, R.T. (1992) J. Biol. Chem. 267 (30), 21446-21458

20. Tomavo, S., Dubremetz, J.F., and Schwarz, R.T. (1992) J. Biol. Chem. 267 (17), 11721-11728

21. Fankhauser, C., Homans, S.W., Thomas Oates, J.E., McConville, M.J., Desponds, C., Conzelmann, A., and Ferguson, M.A. (1993) J. Biol. Chem. 268 (35), 26365-26374

22. Sipos, G., Puoti, A., and Conzelmann, A. (1995) J. Biol. Chem. 270 (34), 19709-19715

23. Field, M.C., Medina Acosta, E., and Cross, G.A. (1991) Mol. Biochem. Parasitol. 48 (2), 227-229

24. Guther, M.L., Cardoso de Almeida, M.L., Yoshida, N., and Ferguson, M.A. (1992) J. Biol. Chem. 267 (10), 6820-6828

25. Previato, J.O., Jones, C., Xavier, M.T., Wait, R., Travassos, L.R., Parodi, A.J., and Mendonca-Previato, L. (1995) J. Biol. Chem. 270 (13), $7241-7250$ 
Trends in Glycoscience and Glycotechnology Vol.10 No.56 (November 1998) pp.439-453

26. Ferguson, M.A. (1992) Biochem. J. 284 (Pt 2), 297-300

27. Abuin, G., Couto, A.S., de Lederkremer, R.M., Casal, O.L., Galli, C., Colli, W., and Alves, M.J. (1996) Exp. Parasitol. 82 (3), $290-297$

28. Tomavo, S., Dubremetz, J.F., and Schwarz, R.T. (1993) Biol. Cell. 78 (3), 155-162

29. Field, M.C., Menon, A.K., and Cross, G.A. (1991) EMBO J. 10 (10), 2731-2739

30. Bertello, L.A., Andrews, N.W., and de Lederkremer, R.M. (1997) Mol. Biochem. Parasitol. 79, 143-151

31. Turco, S.J., Hull, S., Orlandi, P.A., and Shepherd, S.D. (1987) Biochem. 26, 6233-6238

32. McConville, M.J., Bacic, A., Mitchell, G.F., and Handman, E. (1987) Proc. Natl. Acad. Sci. USA. 84 (24), 8941-8945

33. Turco, S.J., Orlandi, P.A., Homans, S.W., Ferguson, M.A., Dwek, R.A., and Rademacher, T.W. (1989) J. Biol. Chem. 264 (12), $6711-6715$

34. Rosen, G., Pahlsson, P., Londener, M.V., Westerman, M.E., and Nilsson, B. (1989) J. Biol. Chem. 264, 10457-10463

35. McConville, M.J., Homans, S.W., Thomas Oates, J.E., Dell, A., and Bacic, A. (1990) J. Biol. Chem. 265, 7385-7394

36. McConville, M.J., and Bacic, A. (1990) Mol. Biochem. Parasitol. 38, 57-67

37. McConville, M.J., and Blackwell, J.M. (1991) J. Biol. Chem. 266 (23), 15170-15179

38. de Lederkremer, R.M., Lima, C., Ramirez, M.I., Ferguson, M.A., Homans, S.W., and Thomas Oates, J. (1991) J. Biol. Chem. 266 (35), 23670-23675

39. Golgher, D.B., Colli, W., Souto-Padron, T., and Zingales, B. (1993) Mol . Biochem . Parasitol. 60, 249-264

40. Previato, J.O., Jones, C., Goncalves, L.P., Wait, R., Travassos, L., and Mendonca-Previato, L. (1994) Biochem. J. 301, 151-159

41. Smith, T.K., Milne, F.C., Sharma, D.K., Crossman, A., Brimacombe, J.S., and Ferguson, M.A.J. (1997) Biochem. J. 326, 393-400

42. Stevens, V.L., and Raetz, C.R. (1991) J. Biol. Chem. 266 (16), 10039-10042

43. Hirose, S., Ravi, L., Hazra, S.V., and Medof, M.E. (1991) Proc. Natl. Acad. Sci. USA 88 (9), 3762-3766

44. Stevens, V.L. (1993) J. Biol. Chem. 268 (13), 9718-9724

45. Costello, L.C., and Orlean, P. (1992) J. Biol. Chem. 267 (12), 8599-8603

46. Doering, T.L., Masterson, W.J., Englund, P.T., and Hart, G.W. (1989) J. Biol. Chem. 264 (19), 11168-11173

47. Menon, A.K., Eppinger, M., Mayor, S., and Schwarz, R.T. (1993) EMBO J. 12, 1907-1914

48. Menon, A.K., and Vidugiriene, J. (1994) Braz. J. Med. Biol. Res. 27 (2), 167-175

49. Udenfriend, S., and Kodukula, K. (1995) Annu. Rev. Biochem. 64, 563-591

50. Benghezal, M., Benachour, A., Rusconi, S., Aebi, M., and Conzelman, A. (1996) EMBO J. 15 (23), 6575-6583

51. Yu, J., Nagarajan, S., Knez, J.J., Udenfriend, S., Chen, R., and ME, M. (1997) Proc. Natl. Acad. Sci. USA 94, 12580-12585

52. Mensa-Wilmot, K., LeBowitz, J.H., Chang, K.P., Al Qahtani, A., McGwire, B.S., Tucker, S., and Morris, J.C. (1994) Braz. J. Med. Biol. Res. 27 (2), 177-184

53. Mensa-Wilmot, K., LeBowitz, J.H., Chang, K.P., Al Qahtani, A., McGwire, B.S., Tucker, S., and Morris, J.C. (1994) J. Cell. Biol. 124 (6), 935-947

54. Ryan, K.A., Garraway, L.A., Descoteaux, A., Turco, S.J., and Beverley, S. M. (1993) Proc. Natl. Acad. Sci. USA 90, 8609-8613

55. Inoue, N., Kinoshita, T., Orii, T., and Takeda, J. (1993) J. Biol. Chem. 268 (10), 6882-6885

56. Kamitani, T., Chang, H.M., Rollins, C., Waneck, G.L., and Yeh, E. T. (1993) J. Biol. Chem. 268 (28), 20733-20736

57. Miyata, T., Takeda, J., Iida, Y., Yamada, N., Inoue, N., Takahashi, M., Maeda, K., Kitani, T., and Kinoshita, T. (1993) Science 259 (5099), $1318-1320$

58. Hamburger, D., Egerton, M., and Riezman, H. (1995) J. Cell. Biol. 129 (3), 629-639

59. Leidich, S. D., Kostova, Z., Latek, R.R., Costello, L.C., Drapp, D.A., Gray, W., Fassler, J.S., and Orlean, P. (1995) J. Biol. Chem. 270 (22), 13029-13035

60. Schonbachler, M., Horvath, A., Fassler, J., and Riezman, H. (1995) EMBO J. 14 (8), 1637-1645

61. Benghezal, M., Benachour, A., Rusconi, S., Aebi, M., and Conzelmann, A. (1996) EMBO J. 15, 6575-6583

62. Inoue, N., Watanabe, R., Takeda, J., and Kinoshita, T. (1996) Biochem. Biophys. Res. Commun. 226 (1), $193-199$

63. Takahashi, M., Inoue, N., Ohishi, K., Maeda, Y., Nakamura, N., Endo, Y., Fujita, T., Takeda, J., and Kinoshita, T. (1996) EMBO J. 15, 42544261

64. Mohney, R.P., Knez, J.J., Ravi, L., Sevlever, D., Rosenberry, T.L., Hirose, S., and Medof, M.E. (1994) J. Biol. Chem. 269 (9), 6536-6542

65. Chen, R., Udenfriend, S., Prince, G.M., Maxwell, S.E., Ramalingam, S., Gerber, L.D., Knez, J., and Medof, M.E. (1996) Proc. Natl. Acad. Sci. USA 93 (6), 2280-2284

66. Vossen, J.H., Ram, A.F., and Klis, F.M. (1995) Biochim. Biophys. Acta. 1243 (3), 549-551

67. Nakamura, N., Inoue, N., Watanabe, R., Takahashi, M., Takeda, J., Stevens, V.L. et al. (1997) J. Biol. Chem. 272, 15834-15840

68. Masterson, W.J., Raper, J., Doering, T.L., Hart, G.W., and Englund, P.T. (1990) Cell 62(1), 73-80

69. de Lederkremer, R.M., Lima, C.E., Ramirez, M.I., Goncalvez, M.F., and Colli, W. (1993) Eur. J. Biochem. 218 (3), $929-936$

70. Ralton, J.E., and McConville, M.J. (1998) J. Biol. Chem. 273, 4245-4257

71. Conzelmann, A., Puoti, A., Lester, R.L., and Desponds, C. (1992) EMBO J. 11 (2), 457-466

72. Sipos, G., Puoti, A., and Conzelmann, A. (1994) EMBO J. 13, 2789-2796

73. Sipos, G., Reggiori, F., Vionnet, C., and Conzelmann, A. (1997) EMBO J. 16 (12), 3494-3505

74. Buxbaum, L.U., Raper, J., Opperdoes, F.R., and Englund, P.T. (1994) J. Biol. Chem. 269 (48), 30212-30220

75. Buxbaum, L.U., Milne, K.G., Werbovetz, K.A., and Englund, P.T. (1996) Proc. Natl. Acad. Sci. USA 93 (3), 1178-1183

76. Urakaze, M., Kamitani, T., DeGasperi, R., Sugiyama, E., Chang, H.M., Warren, C.D., and Yeh, E.T. (1992) J. Biol. Chem. 267 (10), $6459-$ 6462

77. Doerrler, W.T., Ye, J., Faick, J.R., and Lehrman, M.A. (1996) J. Biol. Chem. 271, 27031-27038

78. Guther, M.L., and Ferguson, M.A. (1995) EMBO J. 14 (13), 3080-3093

79. Guther, M.L., Masterson, W.J., and Ferguson, M.A. (1994) J. Biol. Chem. 269 (28), 18694-18701

80. Guther, M.L., Masterson, W.J., and Ferguson, M.A. (1994) Braz. J. Med. Biol. Res. 27 (2), 121-126

81. Guther, ML, Treumann, A, and MA, F. (1996) Mol Biochem Parasitol 77, 137-145

82. Tomavo, S., Martinage, A., and Dubremetz, J.F. (1992) Parasitol. Res. 78 (7), 541-544

83. Hirose, S., Mohney, R.P., Mutka, S.C., Ravi, L., Singleton, D.R., Perry, G., Tartakoff, A.M., and Medof, M.E. (1992) J. Biol. Chem. 267 (8), 5272-5278 
Trends in Glycoscience and Glycotechnology

Vol.10 No.56 (November 1998) pp.439-453

84. Sutterlin, C., Horvath, A., Gerold, P., Schwarz, R.T., Wang, Y., Dreyfuss, M., and Reizman, H. (1997) EMBO J. 16, 6374-6383

85. Smith, T.K., Sharma, D.K., Crossman, A., Dix, A., Brimacombe, J. S., and Ferguson, M.A.J. (1997) EMBO J. 16, $6667-6675$

86. Schofield, L., and Tachado, S. D. (1996) Immunol. Cell Biol. 74, 555-563

87. Liu, X., and Chang, K. (1992) Proc Natl. Acad. Sci. USA 89, 4991-4995

88. McGwire, B., and Chang, K.P. (1994) Mol. Biochem. Parasitol. 66, 345-347

89. Kink, J.A., and Chang, K.P. (1988) Mol. Biochem. Parasitol. 27, 181-190

90. Joshi, P., Sacks, D., Modi, G., and McMaster, W. (1998) Mol Microbiol 27 (3), 519-530

91. Russell, D.G., Ip, H.S., and Medina -Acosta, E. (1991) in Molecular and Immunological Aspects of Parasitism (Wang, C.C., ed.), pp. 73-85, Washington, D.C., American Association for the Advancement of Science

92. Russell, D.G. (1994) Protoplasma 181, 191-201

93. Rizvi, F.S., Ouaissi, M.A., Marty, B., Santoro, F., and et al. (1988) Eur. J. Immunol. 18 (3), $473-476$

94. Russell, D. (1987) Eur. J. Biochem. 164, 213-221

95. Chaudhuri, G., and Chang, K.P. (1988) Mol. Biochem. Parasitol. 27, 43-52

96. Chaudhuri, G., Chaudhuri, M., Pan, A., and Chang, K.P. (1989) J. Biol. Chem. 264, 7483-7489

97. Brittingham, A., Morrison, C.J., McMaster, W.R., McGwire, B.S., Chang, K.P., and Mosser, D. (1995) J. Immunol. 155, 3102-3111

98. Pimenta, P.F.P., Saraiva, E.M.B., Rowton, E., Modi, G.B., Garraway, L.A., Beverley, S.M., Turco, S.J., and Sacks, D.L. (1994) Proc. Natl. Acad. Sci. USA. 91, 9155-9159

99. Butcher, B.A., Turco, S.J., Hilty, B.A., Pimenta, P.F., Panunzio, M. et al. (1996) J. Biol. Chem. 271 (34), 20573-20579

100. McConville, M.J., Turco, S.J., Ferguson, M.A.J., and Sacks, D.L. (1992) EMBO J. 11, 3593-3600

101. Kelleher, M., Bacic, A., and Handman, E. (1992) Proc. Nat. Acad. Sci. USA. 89, 6-10

102. Sacks, D.L., Pimenta, P.F.P., McConville, M. J., Schneider, P., and Turco, S.J. (1995) J. Exp. Med. 181, 685-697

103. Camara, M., Ortiz, G., Valero, P.L., Molina, R., Navarro, I., Chance, M.L. et al. (1995) Ann. Trop. Med. Parasitol. 89, 243-251

104. McNeely, T., and Turco, S. (1990) J. Immunol. 144, 2745-2750

105. Cappai, R., Morris, L., Aebischer, T., Bacic, A., Curtis, J.M., Kelleher, M., McLeod, K.S., Moody, S.F., Osborn, A.H., and Handman, E. (1994) Parasitology 108, 397-405

106. Handman, E., Schnur, L.F., Spithill, T.W. et al. (1986) J Immunol 137, 3608-3613

107. Shankar, A., Mitchen, T.K., Hall, L.R., Turco, S.J., and Titus, R.G. (1993) Mol. Biochem. Parasitol. 61, $207-216$

108. Opat, A., Ng, K., Currie, G., Handman, E., and Bacic, A. (1996) Glycobiology 6, 387-397

109. Gonzalez, J., Araguth, M.F., and Yoshida, N. (1991) Infect. Immun. 59 (3), 863-867

110. Santori, F. R., Paranhos-Bacalla, G.S., Franco, D.A.S.J., Yamauchi, L.M., Araya, J.E., and Yoshida, N. (1996) Infect. Immun. 64 (4), 10931099

111. Ruiz, R., Rigoni, V.L., Gonzalez, J., and Yoshida, N. (1993) Parasitol. Immunol. 15, 121-125

112. Dorta, M.L., Ferreira, A.T., Oshiro, M.E., and Yoshida, N. (1995) Mol. Biochem. Parasitol. 73 (1-2), 285-289

113. Andrews, N.W., Hong, K.-S., Robbins, E.S., and Nussenzweig, V. (1987) Exp. Parasitol. 64, 474-484

114. Abuin, G., Colli, W., de Souza, W., et al. (1989) Mol. Biochem. Parasitol. 35, 229-237

115. Burleigh, B.A., and Andrews, N. W. (1995) Annu. Rev. Microbiol. 49, 175-200

116. Yoshida, N., Blanco, S.A., Araguth, M.F., Russo, M., and Gonzalez, J. (1990) Mol. Biochem. Parasitol. 39(1), 39-46

117. Yoshida, N., Mortara, R.A., Araguth, M.F., Gonzalez, J.C. et al. (1989) Infect .Immun. 57, 1663-1667

118. Schenkman, S., Jiang, M.S., Hart, G.W., and Nussenzweig, V. (1991) Cell 65 (7), 1117-1125

119. Schenkman, S., Diaz, C., and Nussenzweig, V. (1991) Exp. Parasitol. 72 (1), 76-86

120. Alves, M.J.M., Abuin, G., Kuwajima, V.Y., and Colli, W. (1986) Mol. Biochem. Parasitol. 21, 75-82

121. Schenkman, S., Ferguson, M.A.J., Heise, N., deAlmeida, M.L.C., Mortara, R.A., and Yoshida, N. (1993) Mol. Biochem. Parasitol. 59, 293304

122. Schenkman, S., Kurosaki, T., Ravetch, V., and Nussenzweig, V. (1992) J. Exp. Med. 175 (175), 1635-1641

123. de Titto, E.H. and Araujo, F.G. Acta Trop. 44, 273-282

124. Henriquez, D., Piras, R., and Piras, M.M. (1981) Mol. Biochem . Parasitol. 2, 359-366

125. Schenkman, R.P., Vandekerckhove, F., and Schenkman, S. (1993) Infect. Immun. 61 (3), 898-902

126. Ciavaglia, M. do C., de Carvalho, T.U., de Souza, W. (1993) Biochem. Biophys. Res. Commun. 193 (2), 718-721

127. Garg, N., Postan, M., Mensa-Wilmot, K., and Tarleton, R.L. (1997) Infect. Immun. 65, 4055-4060

128. Andrews, N.W. (1995) Trends Cell Biol 5 (3), 133-137

129. Docampo, R., Scott, D.A., Vercesi, A.E., Moreno, S.N., Santori, F.R., Paranhos Bacalla, G.S., Franco, D.A.S.J., Yamauchi, L.M., Araya, J.E., and Yoshida, N. (1995) Biochem. J. 310, 1005-12

130. Rodriguez, A., Samoff, E., Rioult, M.G., Chung, A., and Andrews, N.W. (1996) J. Cell Biol. 134, 349-362

131. de Diego, J., Punzon, C., Duarte, M., and Fresno, M. (1997) J. Immunol. 159, 4983-89

132. Hall, B.F., Webster, P., Ma, A.K., Joiner, K.A., and Andrews, N.W. (1992) J. Exp. Med. 176 (2), 313-325

133. Hall, B.F. (1993) Semin. Cell Biol. 4 (5), 323-333

134. Homans, S.W., Edge, C.J., Ferguson, M.A., Dwek, R.A., and Rademacher, T.W. (1989) Biochemistry 28 (7), $2881-2887$

135. Ferguson, M.A.J. (1992) Biochem. Soc. Trans. 20, 243-256

136. McConville, M.J. (1995) Aust. N.Z.J. Med. 25, 768-776

137. Barry, J.D. (1997) Parasitol. Today 13, 212-218

138. Ferguson, M.A., Murray, P., Rutherford, H., and McConville, M.J. (1993) Biochem. J. 291, 51-55

139. Engstler, M., Reuter, G., and Schauer, R. (1993) Mol. Biochem. Parasitol. 61 (1), 1-13

140. Garg, N., Tarleton, R.L., and Mensa-Wilmot, K. (1997) J. Biol. Chem. 272, 12482-12491

141. James, S.L., and Nacy, C. (1993) Curr. Opin. Immunol. 5 (4), 518-523

142. James, S. (1995) Microbiol. Rev. 59 (4), 533-547

143. Camargo, M.M., Almeida, I.C., Pereira, M.E.S., Ferguson, M.A.J., Travassos, L.R., and Gazzinelli, R.T. (1997) J. Immunol. 158, 5890- 
5901

144. Camargo, M.M., Andrade, A.C., Almeida, I.C., Travassos, L.R., and Gazzinelli, R.T. (1997) J. Immunol. 159, 6131-6139

145. Schofield, L., and Hackett, F. (1993) J. Exp. Med. 177 (1), 145-153

146. Tachado, S.D., and Schofield, L. (1994) Biochem. Biophys. Res. Commun. 205 (2), 984-991

147. Tachado, S.D., Gerold, P., McConville, M.J., Baldwin, T., Quilici, D., Schwarz, R.T., and Schofield, L. (1996) J. Immunol. 156 (5), 18971907

148. Proudfoot, L., Nikolaev, A.V., Feng, G.J., Wei, X.Q., Ferguson, M.A.J., Brimacombe, J.S., and Liew, F.Y. (1996) Proc. Natl. Acad. Sci. USA 93, 10984-10989

149. Descoteaux, A., Turco, S.J., Sacks, D.L., and Matlashewski, G. (1991) J. Immunol. 146, 2747-2753

150. Proudfoot, L., O’Donnell, C.A., and Liew, F.Y. (1995) Eur. J. Immunol. 25, 745-750

151. Liew, F. Y., Wei, X.Q., and Proudfoot, L. (1997) Philos. Trans. R. Soc. Lond. B. Biol. Sci. 352, 1311-1315

152. Tachado, SD., Gerold, P., Schwarz, R.T., Novakovic, S., McConville, M.J., and Schofield, L. (1997) Proc. Natl. Acad. Sci. USA 94, 40224027

153. Schofield, L., Vivas, L., Hackett, F., Gerold, P., Schwarz, R.T., and Tachado, S. (1993) Ann. Trop. Med. Parasitol. 87 (6), $617-626$

154. Proudfoot, L., O’Donnell, C.A., and Liew, F.Y. (1995) J. Immunol. 25, 745-750

155. Descoteaux, A., Salvatore, Y.L., Turco, J., and Beverley, S.M. (1995) Science 269, 1869-1871

156. Descoteaux, A., Matlashewski, G., and Turco, S.J. (1992) J. Imunol. 149, 3008-3015

157. Giorgione, J.R., Turco, S.J., and Epand, R.M. (1996) Proc. Natl. Acad. Sci. USA 93, 11634-11639

158. Bulow, R., Nonnengasser, C. and Overath, P. (1989) Mol. Biochem. Parasitol. 32, 85-92

159. Ziegelbauer, K., Stahl, B., Karas, M., Stierhof, Y.D., and Overath, P. (1993) Biochem. 32, 3737-3742

160. Andrews, N.W., Robins, E.S., Ley, V., Hong, K.S., and Nussenzweig, V. (1988) J. Exp. Med. 167, 300-314

161. Zamze, S.E., Ferguson, M.A.J., Collins, R., Dwek, R.A., and Rademacher, T.W. (1988) Eur. J. Biochem. 176, 527-534

162. Goncalves, M.F., Umezawa, E.S., Katzin, A.M., de Souza, W., Alves, M.J., Zingales, B., and Colli, W. (1991) Exp. Parasitol. 72 (1), $43-53$

163. Campetella, O., Henriksson, J., Aslund, L., Frasch, A.C., Pettersson, U., and Cazzulo, J.J. (1992) Mol. Biochem. Parasitol. 50 (2), $225-234$

164. Malchiodi, E.L., Chiaramonte, M.G., Martinez, J.A., Zwirner, N. W., Margni, R.A., and Cazzulo, J.J. (1993) Immunol Lett 35 (1), $59-62$

165. Tomas, A.M., Miles, M.A., and Kelly, J.M. (1997) Eur. J. Biochem. 244, 596-603

166. Fresno, M., Hernandez, M.C., de Diego. J., Rivas, L., Scharfstein, J., and Bonay, P. (1994) Braz. J. Med. Biol. Res. 27 (2), $431-437$

167. Bouvier, J., Schneider, P., and Etges, R. (1995) Methods Enzymol. 248, 614-633

168. Garg, N., Nunes, M.P., and Tarleton, R.L. (1997) J. Immunol. 158, 3293-3302

169. Wizel, B., Nunes, M.P., and Tarleton, R.L. (1997) J. Immunol. 159, 6120-6130

170. Low, H.P., Santos, M.A.M., Wizel, B., and Tarleton, R.L. (1998) J. Immunol. 160, 1817-1823

Received on June 2, 1998, accepted on June 30,1998

Nisha Garg
Graduated in Biochemistry/Molecular Biology
from Haryana Agriculture University, India. The
field of interest for graduation was the "Genet-
ics of nitrogen fixation and nodulation in legume
crops" which was later pursued with funding
from Common-Wealth and Council of Scientific
and Industrial Research (CSIR) at AFRC unit
of N ${ }_{2}$ fixation, University of Sussex, UK and
Haryana Agriculture University, India, respec-
tively. Since 1993 , professional activity in the
field of Biology of parasitic kinetoplastids is
developed at the Department of Cellular Biol-
ogy of the University of Georgia, USA. Spe-
cifically, as an Assistant Scientist, I am inter-

ested in understanding the biological significance of the glycosylphosphatidylinositols, the major mode of surface protein anchorage in parasitic protozoans; characterization of GPI-biosynthesis pathway and utilization of enzymes involved in GPIbiosynthesis as chemotherapeutic targets. Other interest involves the understanding of the course of Chagas' disease caused by parasitic protozoan Trypanosoma cruzi, the identification and characterization of the $T$. cruzi molecules that are targets of host immune responses and the utilization of genes encoding these target molecules as vaccine candidates for prevention and treatment of T. cruzi infection. 